\title{
Strengthening of Adat Village and The Value of Local Wisdom in Bali in Prevention Commercial Sexual Exploitation of Children (CSEC)
}

\author{
I Made Wirya Darma, Ni Nyoman Juwita Arsawati*, and I Gusti Agung Ayu Mas Triwulandari \\ Universitas Pendidikan Nasional Denpasar \\ *juwitaarsawatihukum@gmail.com
}

Published: 25/02/2021

\begin{abstract}
How to cite:
Darma, I, M, W., Arsawati, N, N, J., Triwulandari, I, G, A, A, M. 2021. Strengthening of Adat Village and The Value of Local Wisdom in Bali in Prevention Commercial Sexual Exploitation of Children (CSEC). Sociological Jurisprudence Journal. Volume 4 Issue 1. Page 23 30. https://doi.org/10.22225/scj.4.1.1594.23-30
\end{abstract}

\begin{abstract}
The negative impact of the development of the tourism industry, information technology and communication and transportation in addition to problems of poverty, unemployment, dropping out of school, and limited employment is still an unresolved problem, thus further encouraging the Commercial Sex Exploitation of Children. Through strengthening Desa Adat and regulating child protection in awig-awig or pararem regarding strengthening the position of children in Bali by incorporating the concept of local wisdom will certainly be able to reduce the number of sexual violence and child exploitation in Bali, so that synergy in solving positive legal cases will be easier effective, because if a case occurs, it will be resolved first within the scope of the village through prevailing customary law before continuing into the realm of positive law. Arranging and determining Awig-awig who adopt local wisdom concepts and values including Tri Hita Karana, Tri Kaya Parisudha, and Tat Twam Asi are able to reflect religious, ritual and upakara elements in preventing sexual violence and exploitation of children.
\end{abstract}

Keywords: Shild commercial; sex exploitation; strengthening customary institutions; the concept of local wisdom

\section{I. . INTRODUCTION}

Globalization and industrialization and all its changes in implications tend to raise the practice of Commercial Sexual Exploitation of Children (hereinafter abbreviated CSEC). This is related to the negative impact of the development of the tourism industry, information and communication technology and transportation. In addition to these factors, the problem of poverty, unemployment, school dropout, and limited employment are still unresolved issues, which further raise CSEC. Poverty is indeed still a dominant problem in Indonesia. One result of poverty that is directly related to CSEC is school dropout. The practices behind commercial sexual exploitation of children include rape, kidnapping, robbery, pseudo/contract marriage, illegal adoption, illegal immigration, forced labor, extortion, and brides by order.

Anticipation of crime can be done by effectively functioning criminal law instruments through law enforcement. Acts considered as violations of law can be resolved through preventive and repressive measures. Submitting a trial and subsequently convicting a person for a crime is a form of repressive measure. Meanwhile, legal protection is preventive measure, namely the protection or prevention of all arbitrary actions committed by humans and given the rights to protect themselves both individually and collectively in maintaining life and life within the society (Amir: 2019).

Regarding the substance of the law, regulations on online child sexual abuse/exploitation issue varied from one another, or this problem are not regulated, or the regulations under national law use different terminology and elements. Meanwhile, the formal law has several aspects that need to be clarified: the 
investigation mechanism requires special methods, but the procedural law has not provided clear guidance on this matter (Sofian: 2018).

Indonesia, known as legal pluralism, implements not only positive legal system rules, but also recognizes the existence of adat law that is recognized and believed by indigenous peoples. The application of these laws in some cases can considered effective as the sanctions imposed are not criminal but a form of development from a moral perspective. So that the sanctions felt by the perpetrators will have a deterrent effect. In applying adat sanctions, several approaches aside of legal approach were used, including the concept of local wisdom in the community. In this study, the island of Bali was made the object of research because as one of the tourist destinations, it is also vulnerable to the crime of child sexual exploitation. Although the island of Bali is known to be quite small, it has a tourism destination that was once the best destination in the world, but the famous Bali island at the level of international tourism, does not strictly leads to good outcomes, this is because of the advanced development of tourism and the globalization may change the Balinese traditional patterns and patterns of life.

Globalization provides a lot of freedom for people to be able to carry out their activities, this greatly influences the development of existing values in society such as the value of local wisdom, norms that grow in society namely awig-awig, and the divine value which includes the teachings of Hindu religion. Those things have an impact on increasing cases of violence against women and children occurring in Bali, such as sexual violence, exploitation of children, polygamy, and so on, as a result of surrounding influences and the change of era.

Regardless of what is currently happening, all forms of law enforcement must be improved, including by strengthening the role of customary law regarding the resolution of cases of commercial sexual exploitation of children. Recognition of the existence of customary law and the role given to Adat Village (Adat village is a governmental unit administered by tradiotional society and has the rights to administer the area and livings within the area of adat village. Adat village has various terms in different regions, such as nagari, huta, marga and negeri). Village in Bali enables Pakraman village within the neighborhood to make a regulation called awig-awig (regulation made by the adat village or the community of banjar adat or even pararem (result of decision making within the paruman village or banjar containing the practical regulation of pakraman village awig-awig and/or anything else related to the principle beyond the implementation of the existing awig-awig) in favor of child protection.

Through strengthening the Adat Village and child protection regulation in awig-awig or pararem on solidifying the position of children in Bali by incorporating the concept of local wisdom one of which is the value of Tri Hita Karana (three harmonic relations resulting in the joy of humankind. These there relations are Parahyangan (relation between human and God), Palemahan (relation between human and environment), and Pawongan (relation among human)) accordance with mewacara dharma agama within the Pakraman village or banjar pakraman, serves a concept of natural law in modern civilization codified in the form of written awig-awig (Surpha: 1993), which is believed to be able to reduce the number of sexual violence and exploitation of children in Bali. Awig-awig applicable for the adat community in Bali is a rule made by the adat village krama (adat community in Bali) that are used as guidelines in the implementation of daily life, so that the handling of cases of CSEC can be resolved first through traditional institutions before proceeding to the framework of positive law.

Based on this, the research will discuss the strengthening of traditional institutions and the concept of local wisdom in Bali in the prevention of commercial sexual exploitation of children (CSEC).

\section{METHOD}

This research is a normative juridical study that compares national legal regulations with traditional regulations related to the prevention of sexual exploitation of children. The legal material used is primary legal material and secondary legal material. The collection of legal materials is done by library research techniques. The problem approach is carried out using the statutory approach, the legal concept approach, and the comparative approach. Analysis of legal material is done qualitatively.

\section{III.RESULT AND DISCUSSION}


Regulation on the Prevention of Sexual Violence against Children in the Province of Bali through Regional Regulation of the Province of Bali No. 6 of 2014 on Child Protection

The imposition of this Regional Regulation (Peraturan Daerah-PERDA) is a mandate from the Regulation of the Minister of Internal Affairs No.1 of 2014 on the Establishment of Regional Legal Instrument. In this Regional Regulation especially in Article 10, which is about fulfilling the right of children to survive, including: the right to a decent standard of living, the right to get nutritious food, the right to get food and clothing and the right to receive health services. Whereas the intended protection of children is protection from violence, exploitation and discrimination including trafficking. Besides, children are given the opportunity to participate, namely to hear their opinions and to be able to play an active role in their community in accordance with their potential in various matters that concern the child's interests.

The policies outlined in this Regional Regulation also have not been implemented properly considering that this Regional Regulation has just been established, it is expected that in the future, the implementation of child protection regulated in this Regional Regulation is immediately implemented and can provide protection for children from the improper treatment they should not receive. Existing studies have discerned factors that differentiate Commercial Sexual Exploitation of Children (CSEC) victims from sexual abuse victims, yet no research has been conducted to discriminate which items in a high risk population of youth are most predictive of CSEC (Panlilio, C. C., Miyamoto, S., Font, S. A., \& Schreier, H. M., 2019). CSEC during adolescence predicted higher levels of general post-traumatic symptoms, anxious arousal, intrusive experiences, defensive avoidance, and dissociation (Lanctôt, N., Reid, J. A., \& Laurier, C., 2019).

\section{Strengthening of Adat Villages in the Prevention of Commercial Sexual Exploitation of Children (CSEC)}

The problem of commercial sexual exploitation of children (CSEC) regarding violations of human rights, the concept of human rights has been explained in Law Number 39 of 1999 concerning Human Rights, stated that Human Rights (HAM) is a set of rights attached to the nature and the existence of human beings as creatures created by God Almighty and is a gift that must be respected, upheld, and protected by the rule of law, the government, and everyone for the honor and protection of human dignity.

CSEC prevention can be realized with the participation of community members through the enforcement and protection of human rights. The enforcement and protection of human rights are not only carried out by the institutions established by the State but by customary institutions, in this case, the Adat Villages in Bali. The Adat Village is currently faced with complex problems related to child protection. As a public service entity that is directly dealing with the community, the Adat Village is the frontline in handling child protection cases.

Violence against children in various forms such as physical, psychological, sexual and emotional violence mostly occurs in rural areas. In the village, a myriad of child problems occur, cases of neglect or exploitation, vulnerability to disasters and children with legal problems mostly occur in the village. The village should be more responsive to the problems faced concerning child protection. Because the village is closer to children, they are the ones who witness the complexity of the children's problems in the village all the time. Compared to higher government structures, the village is directly facing and adjacent to children. Unfortunately, the village officials were not well prepared to respond to children problems that have become more popular lately. The problem is that the village does not have adequate institutional tools to respond to various child protection cases. There are almost no institutions in the village that have the main tasks and functions to take care of this problem.

In the village government structure there is the Head of People's Welfare Affairs (Kaur Kesra) who takes care of social problems in the village. The staff in this section is responsible for everything related to matters of welfare for citizens. The problem is, there is no special duty of this apparatus attached to the matter of child protection. To deal with problems related to children, they usually work closely with the PKK and Karang Taruna. And even then usually limited to counseling that is not continuous. The problem is, the PKK has too many matters ranging from counseling and education to the community, including small things monitoring mosquito larvae so that matters relating to child protection tend to be 
neglected. If there are symptoms of a child protection case, it is responded to very late. As a result, the case handling is not optimal. To this date, there has not been a child protection group (KPAD) that actually runs. No wonder the problem of child protection in the village was sporadically attacked by many parties but remains unfocused.

In addition to the absence of village officials or institutions in the village that focus on welfare and child protection, the budget allocated for child protection activities is very limited. Many village officials do not allocate village funds to respond to child protection cases. However, if we look into the existing regulations, village funds can be allocated for child protection.

Referring to the Ministerial Regulation of the Minister of Village No 5/2015 concerning the Determination of Priority in the Use of Village Funds, village funds are prioritized to finance development expenditure and empower village communities. This means that there is actually an opportunity for the village to allocate part of its budget for child protection. Referring to the Ministerial Regulation of the Minister of Village, in the field of development, village funds are prioritized to build, maintain, and develop, among others: First, meeting basic needs, such as the development of village health posts and maternity clinic (polindes); integrated healthcare center (posyandu), Early Childhood Education and Development (PAUD). Second, village facilities and infrastructure, such as village roads, farm roads, village reservoir, new and renewable energy development, village-scale clean water management, tertiary irrigation maintenance, fisheries cultivation, facilities and production in the village. Third, local economic potential, such as the development of village-owned business entity (BUMDes), village markets, fish auctions, food barns, organic fertilizer and food, local seeds, collective livestock, boat moorings, shepherds, tourist villages, appropriate technology for processing agricultural and fishery products. And fourth, sustainable use of natural resources and the environment, such as village-owned forests and waste management.

While in the field of empowerment, village funds are prioritized to improve the quality of the village planning process, support economic activities both through BUMDes and community business groups, and increase the capacity of village community empowerment cadres. And organizing activities through the formation and facilitation of paralegals to provide legal assistance to villagers. Fifth, organizing health promotion and clean and healthy life movement, supporting village activities and community management of village and community forests, increasing the capacity of community groups. Namely through productive economic business groups, women, farmers, poor communities, fishermen, craftsmen, observers of child protection, youth, others according to village conditions.

From the Ministerial Regulation, there are actually opportunities for villages for two big things. First, the development of child protection infrastructure facilities such as the construction of PAUD buildings, children's studios, smart homes, safe houses can be allocated in development posts or infrastructure. The village must be encouraged not only to build infrastructure such as village roads, bridges, village halls as it has been happening but must be encouraged to allocate pro-child development budgets. Village officials and Village Consultation Body (BPD) must know that one-third of the villagers are children. Second, in community empowerment, the budget can be allocated to strengthen village development cadres, especially children observers and child rights activists in the village. The village must indeed make a breakthrough related to the use of village funds that are more pro-child.

In this regard, the village needs to be empowered by the central or local government to strengthen the understanding of village officials regarding child rights and protection. So far, the village apparatus has always stated that there were no written instructions related to the use of village funds from the district/ city. This is more due to the understanding of village officials related to Law No. 6 of 2014 and Ministerial Regulation of the Ministry of Village No. 5 of 2015 concerning Determination of Priority in Village Development. At the ministry level, we encourage the Ministry of Disadvantaged Villages and Transmigration and the Ministry of Women's Empowerment and Child Protection to move quickly so that coordination between agencies is immediately established. The issue of allocating village funds for child protection is more a matter of awareness and commitment of the parties to the fulfillment of children's rights and protection. Villages with a myriad of issues related to child protection need to be assisted and encouraged so that there is courage in village officials to allocate budgets to fulfill children's rights. Villages need to be assisted so that they develop a child responsive budget. And however, the village is the spearhead of protecting children from all forms of violence and mistreatment 
(Paulus Mujira, 2016).

\section{The Existence of the Concept of Local Wisdom in Bali in Preventing Commercial Sexual Exploitation of Children (CSEC)}

Globalization and industrialization and all its changes in implications tend to raise the practice of CSEC. This is related to the negative impact of the development of the tourism industry, information and communication technology and transportation. In addition to these factors, the problem of poverty, unemployment, school dropout, and limited employment are still unresolved issues, which further raise CSEC. Poverty is indeed still a dominant problem in Indonesia. One result of poverty that is directly related to CSEC is school dropout. The process of child sexual prostitution and child sexual tourism here must be taken into account actually in the supervision that must be carried out by the Government and also law enforcement, that the occurrence of sexual exploitation of children is also facilitated by the parties who are accustomed to carrying out the provision of services in the tourism sector: 2013).

The forms of commercial sexual activity against children, both the Declaration of the World Congress Against Commercial Sexual Exploitation of Children as well as the provisions of the CRC and the Child Protection Act define that commercial sexual exploitation of children includes sexual misconducting of children by adults by coercion, giving money or the like to the child concerned or to a third party, children are made as sex objects and commercial objects. Sexual exploitation Commercialization can also be seen in the form of coercion and violence against children, in the form of forced labor and modern forms of slavery (Sirait: 2018).

Furthermore, leading factors of children falling as victims of commercial sexual exploitation are closely related to the education provided by their families that builds the pattern of their behavior. The inability of a family to fulfill the functions/duty that they are supposed to, especially in providing protection and affection, as well as education and socialization of children, results in the coercion of children to enter into commercial sexual exploitation.

In a sense, it has been unraveled other contributing factors to the entry of children into the world of commercial sex are:

Tradition of young marriage and easy divorce.

Strong belief that having sex with a child who is still a virgin can make a man stay young and increase masculinity.

The phenomenon of rural-urban migration carried out by uneducated workers.

Consumptive urban lifestyle.

Life that only thinks about the present without having to estimate it.

Commercial sexual exploitation of children (CSEC) includes traditional practices that are often entrenched in cultural beliefs and globalization as well as new technologies which expose a number of different and constantly changing challenges. In the end, the demand for children as sex partners for any purpose leads to commercial sexual exploitation of children. Nonetheless, there is a matrix of complex factors that make children vulnerable and which creates forces, situation and condition that allow children to be sexually exploited commercially.

Several factors that affected law enforcement on the handling of commercial child sex exploitation cases are, inter alia:

\section{Legal Factor}

In terms of legal factors, in relation to the laws in force in Indonesia, laws are increasingly diverse in form and purpose and almost in everyday life people must obey these regulations. All law enforcement want to do that.

\section{Facilities Factor}

The matter of role is important because law enforcement is more focused on discretion. In law enforcement, discretion is very important because:

There is no law that can regulate all human behaviour 
There are delays to adjust the legislation with developments in society, causing uncertainty.

Lack of funds to implement legislation as desired by the legislators.

There are individual cases that require special handling.

Facilities in the field of law must really run well because these facilities become a support for the smooth enforcement of the law in Denpasar. The facilities referred to include the criminal proceedings.

Non-Law Factor

The community according to the Child Protection Act has obligations and responsibilities towards the protection of children which are carried out through activities involving the community in the implementation of child protection. Community participation can be done individually or in groups. When done in groups the implementation is carried out in the form of child protection institutions, social welfare institutions, social organizations, educational institutions, mass media, and the business world. The law also mandates that in carrying out this community role to involve academics, this is very useful for educating the community through socialization and all other forms of education regarding children's rights and legislation concerning children.

Furthermore, the role of the community in efforts to protect children is regulated in article 72 paragraph (3) of the Child Protection Act and is divided into eight activity points. the eight points are the elaboration of the implementation of obligations and responsibilities for the protection of children through community participation that can be developed in accordance with the conditions encountered in the community. If exploitation of children has already occurred, the community in the rule of law should report to the authorities in the event of a violation of the Rights of the Child. The role of Adat Villages does not stop only with reporting, it includes other obligations that must be carried out by playing an active role in eliminating negative labeling of children victims of exploitation and in the process of rehabilitation as well as social reintegration for children. At the level of prevention and supervision of the implementation of child protection that can be done by Adat Villages, among others, is to provide information on socialization and education regarding children's rights and laws and regulations concerning children; monitor, supervise and take responsibility for the implementation of child protection; provide facilities and infrastructure as well as create an atmosphere conducive to children's development. By knowing what are the obligations and responsibilities outlined in the role of Adat Villages in child protection, in the future, the role of monitoring, supervision and prevention of exploitation of children can be done more effectively so that no more children lose their rights to life.

Prevention efforts are processes, ways, actions to prevent something from happening. For the community, family, or parents, it is necessary to have consistent and continuous policies, services, resources and training in preventing exploitation of children. In this case, strategies for preventing sexual violence and exploitation of children include: Primary prevention for all parents to improve their caregiving abilities and to ensure that abuse does not occur, including adequate child care and services, supportive workplace policies, and training life skills for children. What is meant by life skill training includes conflict resolution without violence, skills in dealing with stress, resource management, making effective decisions, effective interpersonal communication, guidance or guidance and child development, including drug abuse; Secondary prevention is aimed at high-risk groups in efforts to improve parenting skills, including training and victim services to ensure that mistreatment does not occur in the next generation. Activities undertaken here include conducting home visits for parents who have new children to conduct a self-assessment of whether they are at risk of future violence against children; Tertiary prevention is intended to improve the ability of caregiving to keep mistreatment from happening again, here what is done is integrated services for children who have been victims of violence or exploitation, counseling, stress management training.

Sexual violence and exploitation of children are endless phenomena. There are still many cases of child abuse that have not been handled optimally due to the reluctance of the victims' families to report the violence. The chain of acts of sexual violence and exploitation of children needs to be broken because children with past experiences of violence will also tend to cause trauma and violence as they grow up. Children who are victims of sexual violence and exploitation need to be dealt with specifically because victims will experience both physical and mental trauma. Handling violence against children requires collaboration from parents, families, communities and the government. Therefore efforts to 
handle community-based child violence need to be done to break the chain of violence.

In addition, prevention efforts become an important part of efforts to break the chain of violence. These efforts can be done through the earliest and closest social environment, namely family, relatives, and so on, extends to the community and control of social media and mass media by the government. There needs to be a joint awareness, that acts of violence are extraordinary crimes that can interfere with the development of children in the future, and will impact on the disruption of the education process and childcare in existing social institutions.

\section{IV.CONCLUSION}

Conclusions should answer the objectives of the research. Tells how your work advances the field from the present state of knowledge. Without clear Conclusions, reviewers and readers will find it difficult to judge the work. The role of Adat Villages does not stop only with reporting, it includes other obligations that must be carried out by playing an active role in eliminating negative labeling of children victims of exploitation and in the process of rehabilitation as well as social reintegration for children. At the level of prevention and supervision of the implementation of child protection that can be done by Adat Villages, among others, is to provide information on socialization and education regarding children's rights and laws and regulations concerning children; monitor, supervise and take responsibility for the implementation of child protection; provide facilities and infrastructure as well as create an atmosphere conducive to children's development. By knowing what are the obligations and responsibilities outlined in the role of Adat Villages in child protection, in the future, the role of monitoring, supervision and prevention of exploitation of children can be done more effectively so that no more children lose their rights to life.

The role of local wisdom in preventing violence against children is very urgent besides just doing prevention through socialization, education, character development, and sex education. Because of the philosophical cultivation of religion and local wisdom, the values or teachings of the ancestors as implanted from the womb until the child is mature and able to act alone. Because the value of local wisdom that influences human personal life makes it a noble and moral creature so that it suppresses the passions and desires to do crimes. Therefore, the inculcation of the concept of local wisdom is a very effective thing, starting with the synergy between customary institutions/Adat Villages, combined with norms, religious values, and teachings, it can suppress and even prevent acts of sexual violence against children. Formulating Awig-awig which adopts the concepts and values of local wisdom. Prevention of sexual violence against children can be prevented if the application of the conceptions of Hindu teachings is applied both in primary, secondary and tertiary relationships in everyday life.

For the government as the implementing agency of the law as well as the legislative body (the House of Representatives) as the regulator, these two state institutions must work together in implementing the ideals of the nation in terms of protecting children from child sexual violence and child exploitation, and the Adat Village to play an active role in preventing the occurrence of acts of sexual violence against children through the rules established in Awig-Awig and aggravating customary sanctions for perpetrators of child sexual violence and exploitation of children which is manifested in the form of Perarem.

\section{REFERENCE}

Amir, S.A. (2019). Perlindungan Hukum Bagi Anak Korban Perkosaan Dalam Perspektif Hak Asasi Manusia. In Kota Palu Sulawesi Tengah. Accessed on 28 January 2019. http://pasca.unhas.ac.id

Lanctôt, N., Reid, J. A., \& Laurier, C. (2019). Nightmares and flashbacks: The impact of commercial sexual exploitation of children among female adolescents placed in residential care. Child abuse \& neglect, 104195.

Lisanawati, G. (2013). Cyber Child Sexual Exploitation dalam Perspektif Perlindungan atas Kejahatan Siber. Pandecta: Research Law Journal, 8(1).

Panlilio, C. C., Miyamoto, S., Font, S. A., \& Schreier, H. M. (2019). Assessing risk of commercial sexual exploitation among children involved in the child welfare system. Child abuse \& neglect, 87, 88-99.

Paulus Mujira. (2016). Alokasi Dana Desa Untuk Perlindungan Anak. Accessed on 12 February 2019. https:// id.beritasatu.com/home/alokasi-dana-desa-untuk-perlindungan-anak/152060 
Strengthening of Adat Village and The Value of Local Wisdom in Bali in Prevention Commercial Sexual Exploitation of Children (CSEC)

Sirait, A. M. (2018). Eksploitasi Seksual Komersial Mengintai Anak Kita. Jurnal Legislasi Indonesia, 5(3), 87-92.

Sofian, A. (2018). Perlindungan Hukum Anak di Ranah Daring: Trend Global. Jakarta: Binus University Faculty of Humanity.

Surpha, W. (1993). Eksistensi Desa Adat di Bali. Denpasar: Upada Sastra. 